\title{
The Effect of Sharia Principles Application and Service Againts Customer Satisfaction of Sharia Financial Services Cooperative In Central Java
}

\author{
Muhammad Tho'in \\ Islamic Economic Study Program, STIE-AAS, Central Java, Indonesia \\ Email:thoin@stie-aas.ac.id
}

\begin{abstract}
The purpose of this research is to know the Application effect of sharia principles and service againts customer satisfaction level of murabahah financing product in sharia financial services cooperative in Central Java. The research method is using multiple linear regression test, $t$ test, $F$ test, and $R_{2}$ test. The results showed that, from the $t$ test results, the service variables proved to be partially significant effect on customer satisfaction with the result of $t_{\text {count }}=$ $5.821>\mathrm{t}$ table $=2.035$. While the application of sharia principles variable While the variable application of sharia principles partially has no significant effect on satisfaction with the result $\mathrm{t}_{\text {count }}=-0.333>\mathrm{t}$ table $=-2.035$. Then, from the results of the $\mathrm{F}$ test of both variables, it simultaneously proved to have a significant effect on satisfaction with the results of $F_{\text {count }}$ value $30.613>F$ table 4.22. From $\mathrm{R}^{2}$ test, it is found that the influence of both variables is $65,7 \%$ against customer satisfaction, means independent variable that is application of sharia principles and service influenced simultaneously equal to $65,7 \%$ to dependent variable that is customer satisfaction, while the rest $34,3 \%$ influenced by other variables outside the two variables used.
\end{abstract}

Keywords: sharia principles, service, customer satisfaction

\section{Introduction}

Talk about the pattern of transactions that exist in the community, where people have a tendency or buying habits of goods by installments either by using conventional financial services or using sharia financial services, but we found that most of the people are still very likely to choose a conventional financing system, this is based on one of the causes that is the lack of understanding of the community, especially the Muslim about the obligation to run the economy in sharia, and also most of the community who still do not understand the products offered by sharia financial institutions, especially products that exist in Sharia financial services cooperative.
However, the people cannot be blamed too. It happens because one of the weaknesses possessed by Sharia financial system is a various contract rules which is considered quite complicated by come people when compared with the conventional financial system that uses the interest system. As a Muslim, this can be solved by using sharia financing. As a Muslim this should be solve by using sharia financing products that is buy-sell agreement murabahah, because when compared with other types of agreement in the sharia financial system, murabahah agreement has a fairly easy requirement that customers only need to apply for purchase of goods to the Sharia financial services cooperatives (KJKS), then the 
International Journal of Economics, Business and Accounting Research (IJEBAR) .

Peer Reviewed - International Journal

Vol-2, Issue-1, 2018 (IJEBAR)

ISSN: 2614-1280, https://jurnal.stie-aas.ac.id/index.php/IJEBAR

Sharia financial services cooperatives KJKS buy goods desired by the customer, then the goods are sold to customers by explaining to the customer from the beginning what the cost of goods purchased from it and how the benefits taken by the Sharia financial services cooperative, then paid in a way in accordance with the agreement which has been agreed upon by both parties.

Then in addition to ensuring customers are satisfied with the products of KJKS, the KJKS need to reward customers by providing quality services to customers, of course this can foster public confidence in the KJKS and financial institutions in general, thus encouraging people to always use the services available in sharia financial institutions especially sharia financial services cooperatives.

Implementation of sharia principles is very important in the implementation of financing at a syariah financial institution, because the core of sharia transactions lies in the contract that was carried out, some previous research has examined the effect of application of Sharia principles and service to customer satisfaction, but has not specifically explained about its effect on customer satisfaction of murabahah financing that is considered very needed by the community.

Murabahah financing is the most widely implemented contract in a sharia financial institution in Indonesia, both sharia financial institution in the form of banking and non-banking when compared with other contracts such as akad mudharabah, musyarakah and others. Where the profit taking from mudarabah and musyarakah contracts use the profit sharing system from the profit of its business which is of course more complicated the regulations implemented therein. This becomes one of the driving force of Indonesian Muslim community prefer to use murabahah financing product because it is easier and the most important is in accordance with existing Islamic sharia principles.

Therefore, it is very interesting to conduct research, to see the application effect sharia principles and services againts customer satisfaction of murabahah financing that exist in Sharia Financial Services Cooperative in Central Java.

\section{LITERATURE REVIEW}

\subsection{Service Quality}

Service quality is every action or activity which is offered by a party to an intangible party and does not give rise to any ownership (Kotler, 2002: 83).

According to Tho'in (2011) the quality of service becomes an important item to be considered. In order for the services provided can be good quality and can provide satisfaction on the consumer then the company should pay attention to the various dimensions that can create and improve service quality.

According to Royne (1994) service quality becomes the main component, because the main products of the bank that is credit is an offer that is not different and bank services are easily imitated. In this modern age technology is growing so rapidly and all financial institutions vying to offer their products, in general all products of Islamic financial institutions are almost the same from one to another and what distinguishes is the quality of the service itself, so that service becomes the main factor to provide satisfaction to customers.

The quality service plays an important role in shaping customer satisfaction, it is also highly related in providing benefits for the company. The higher the quality provided by the company 
International Journal of Economics, Business and Accounting Research (IJEBAR) .

Peer Reviewed - International Journal

Vol-2, Issue-1, 2018 (IJEBAR)

ISSN: 2614-1280, https://jurnal.stie-aas.ac.id/index.php/IJEBAR

then customer satisfaction will also be higher. (Panjaitan and Yuliati, 2016: 266).

\subsection{Customer Satisfaction}

According to Kotler (1996: 46) customer satisfaction is the level of one's perception after comparing perceived performance with hope. Satisfaction is from all existing members where one can work well. If the service is appropriate, it will be very difficult if there is satisfaction and cost if it will not be satisfied.

Customer

satisfaction or dissatisfaction is a customer's response to the evolution of disconfirmation discrepancies perceived between previous expectations and perceived real performance. In this increasingly fierce business competition, more and more producers are involved in meeting the needs and desires of customers, thus causing every business entity to place customer satisfaction as the main objective (Tjiptono, 1997: 24).

\subsection{Sharia Principles}

Islamic law is a rule of law established by Allah SWT for the benefit of all mankind (Tho'in, 2016: 164). In carrying out any transaction in Islam has been determined some things that should not be done to avoid sin, therefore must apply the principles in sharia. The meaning of the word principle itself is the basis and the principle of truth which is the basic reason of thinking. (Fajri, 2008: 671).

While the word sharia itself comes from the root syara'a language which means the way to the source of water, this can also be interpreted as a path towards the source of life. (Jumantoro, 2005: 307).

The Qur'an itself uses the term syirah and sharia in the sense of religion or is defined as a clear path that is shown by God to man. Sharia is also often used as a synonym of the word din and millah which has the meaning of all the rules derived from Allah SWT contained in Al Qur'an and $\mathrm{Al}$ Hadith which is clear its nas. (Arifin, 1974: 200).

Supervision over the implementation of sharia principles in Islamic financial institutions becomes something very urgent and the main thing to do where it is the core of the operational of sharia financial institutions. (Budiono, 2017: 57).

\subsection{Murabahah}

According to Muhammad (2009: 57) murabahah contract is a contract of buysell goods, where the seller clearly states the goods traded, including the cost of goods purchased to the buyer, then the seller requires the buyer of profit or profit in a certain amount. Another definition of murabahah is the buy-sell goods at the cost of goods by adding profits according to the agreement.

In the murabahah agreement, the seller must inform the cost of the purchased product and determine the amount of profit in addition; murabahah can be made for the purchase order and commonly referred to as murabahah to the buyer (Muhammad, 2009: 57).

\section{Research Methods}

The kind of this research is descriptive qualitative. The population taken in this research is all murabahah financing customers in sharia finance services cooperative Mass Group in Central Java. In this study the researchers used probability sampling technique or random sampling and simple. The number of samples taken are 35 person. Where hypothesis testing by 
International Journal of Economics, Business and Accounting Research (IJEBAR) .

Peer Reviewed - International Journal

Vol-2, Issue-1, 2018 (IJEBAR)

ISSN: 2614-1280, https://jurnal.stie-aas.ac.id/index.php/IJEBAR

using multiple linear regression test, $\mathrm{t}$ test, $\mathrm{F}$ test, and test $\mathrm{R}^{2}$.

\section{Results}

\subsection{Multiple Linear Regression Analysis}

This regression analysis aims to examine the effect of independent variables of application of sharia principles (X1) and service variable (X2) to the dependent variable of Satisfaction (Y), from the statistical test results obtained the following results:

Table 1. Multiple Linear Regression Analysis

\begin{tabular}{|c|c|c|c|c|c|c|}
\hline \multirow{2}{*}{\multicolumn{2}{|c|}{ Model }} & \multicolumn{2}{|c|}{$\begin{array}{l}\text { Unstandardized } \\
\text { Coefficients }\end{array}$} & \multirow{2}{*}{$\begin{array}{l}\text { Standardized } \\
\text { Coefficients } \\
\text { Beta }\end{array}$} & \multirow[b]{2}{*}{$\mathrm{t}$} & \multirow[b]{2}{*}{ Sig. } \\
\hline & & B & Std. Error & & & \\
\hline \multirow[t]{3}{*}{1} & (Constant) & 3,974 & 2,921 & & 1,360 &, 183 \\
\hline & $\mathrm{X} 1$ &,- 058 & ,174 &,- 048 &,- 333 & ,742 \\
\hline & $\mathrm{X} 2$ & ,161 & ,028 & ,843 & 5,821 & ,000 \\
\hline
\end{tabular}

Based on the table above, it is known the equation as follow:

$\mathrm{Y}=\mathrm{a}+\beta 1 \mathrm{X} 1+\beta 2 \mathrm{X} 2+\mathrm{e}$

$\mathrm{Y}=3,974-0,058 \mathrm{X} 1+0,161 \mathrm{X} 2+\mathrm{e}$

From the equation of multiple linear regression analysis above, it can be explained some things as follows.

a. The constanta value of 3,974 which shows that if $X$ variable is 0 then the value of customer satisfaction against the application of sharia principles and service is 3,974 .

b. The value of customer perception coefficient against the application of sharia principle on regression model is ($0,058) 0$, means that the variable of the application of sharia principle (X1) has negative effect on customer satisfaction (Y). Each increase of one unit on application of sharia principles variable (X1) then customer satisfaction (Y) decreases 0,058 .

c. The value of customer perception coefficient against the service on regression model is 0,161 , means the service variable (X2) has positive effect against the customer satisfaction (Y). Each increase of one unit service variable (X2) then customer satisfaction (Y) increase 0,161.

\subsection{Uji t}

Table 2. t Test Result

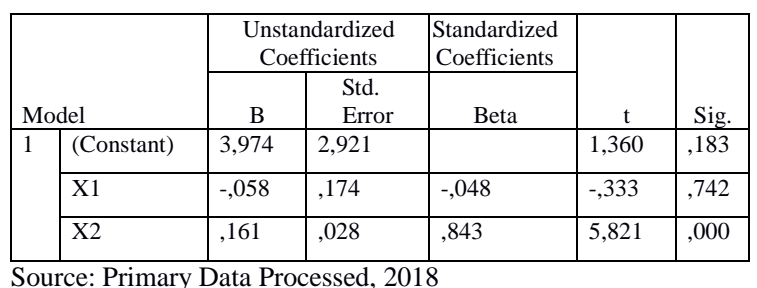

a. X1 (Application of Sharia principles)

Based on the calculation result, it gained $\mathrm{t}_{\text {count }}=-0,333>\mathrm{t}$ table $=-2,035$ and significant value $0,745>\alpha=0,05$.then it can be concluded that $\mathrm{H}_{0}$ which means the application of sharia principles has no significant effect on customer satisfaction of murabahah financing in Mass Group cooperative in Central Java.

b. X2 (Service)

Based on the calculation result gained $\mathrm{t}_{\text {count }}=5,821>\mathrm{t}$ table $=2,035$ and the significant value $0,000<\alpha=0,05$. then it can be concluded that $\mathrm{H}_{0}$ rejected which means the service has significant effect on the customer satisfaction of murabahah financing in in Mass Group cooperative in Central Java.

\subsection{F Test}

F test aims to know whether variable $\mathrm{X} 1$ and $\mathrm{X} 2$ simultaneously has significant effect on $\mathrm{Y}$ variable or not. From the processing data it gained the data as follows: 
International Journal of Economics, Business and Accounting Research (IJEBAR) .

Peer Reviewed - International Journal

Vol-2, Issue-1, 2018 (IJEBAR)

ISSN: 2614-1280, https://jurnal.stie-aas.ac.id/index.php/IJEBAR

Table 3. F Test Result

\begin{tabular}{|l|l|l|l|l|c|c|}
\hline \multicolumn{2}{|l|}{ Model } & \multicolumn{1}{|c|}{$\begin{array}{c}\text { Sum of } \\
\text { Squares }\end{array}$} & df & $\begin{array}{c}\text { Mean } \\
\text { Square }\end{array}$ & F & Sig. \\
\hline \multirow{1}{*}{1} & Regression & 85,077 & 2 & 42,539 & 30,613 &, $000^{\mathrm{b}}$ \\
\cline { 2 - 7 } & Residual & 44,466 & 32 & 1,390 & & \\
\cline { 2 - 7 } & Total & 129,543 & 34 & & & \\
\hline
\end{tabular}

source: Primary Data Processed, 2018

From the Anova result it gained the value of Fcount is 30,613 with significant level of 0,00 . Because of the significant value less than 0,05 and $F$ count $(30,613)$ is bigger than $\mathrm{F}$ table $(4,12)$ then $\mathrm{H}_{0}$ rejected. So it can be concluded that the application of sharia principle and service is simultaneously has significant effect on h]the level of customer satisfaction of murabahah financing in Mass Group cooperative in Central Java.

\section{$4.4 R^{2}$ Test}

This test uses to know how much the influence of application sharia principles variables (X1) and customer variable (X2) against satisfaction variable (Y) then it done determination test $\left(\mathrm{R}^{2}\right)$ and produce the following data:

Table 4. $\mathrm{R}^{2}$ Test Result

\begin{tabular}{|l|c|l|l|l|}
\hline Model & $\mathrm{R}$ & $\mathrm{R}$ Square & $\begin{array}{c}\text { Adjusted } \mathrm{R} \\
\text { Square }\end{array}$ & $\begin{array}{c}\text { Std. Error of the } \\
\text { Estimate }\end{array}$ \\
\hline 1 &, $810^{\mathrm{a}}$ &, 657 &, 635 & 1,179 \\
\hline
\end{tabular}

From the above data seen the value of adjusted coefficient of determination (adjusted $\mathrm{R}^{2}$ ) of 0.657 means that independent variables namely the application of Sharia principles and services simultaneously affecting $65.7 \%$ of the dependent variable is customer satisfaction, while the remaining $34.3 \%$ influenced by other variables outside the two variables used.

\section{Discussion}

From the validity test used SPSS application can be seen that all questions point in questionnaire amount 25 points proved valid, it can be seen from the Pearson Correlation value in every question point is bigger than $r$ table $(0,334)$ besides that every variable also proven reliable seen from the variable application of sharia principles (X1) which there are 5 questions point which in it has Cronbach's Alpha value of 0,706 which is bigger than 0,6 . Then satisfaction variable (Y) which contain 5 questions in it has the value of Cronbach's Alpha of 0,839 which is bigger than 0,6 , it shows that all that variables are reliable.

The value of constant on multiple linear regression analysis is 3,974 it shows that if the variable $X$ is 0 then the value of customer satisfaction on the application of sharia principles and services amounted to 3.974. Then the value of customer perception coefficient on the application of Sharia principles on regression model of (0.058), meaning that variable application of sharia principles (X1) has a negative effect on customer satisfaction variable (Y). Each increase of one unit on variable application of sharia principles (X1) then customer satisfaction (Y) decreased 0,058. While the value of customer perception coefficient on service on regression model equal to 0,161 , meaning service variable (X2) have positive effect to customer satisfaction (Y). Each increase of one unit in service variable (X2) then customer satisfaction (Y) increases 0,161 .

On X1 variable that is the application of sharia principle according to the result of data processed above proved that the variable of the sharia principles partially has no significant effect on customer satisfaction of murabahah financing in KJKS Mass Group in Central Java. From this result shows that the calculation result 
International Journal of Economics, Business and Accounting Research (IJEBAR) .

Peer Reviewed - International Journal

Vol-2, Issue-1, 2018 (IJEBAR)

ISSN: 2614-1280, https://jurnal.stie-aas.ac.id/index.php/IJEBAR

gained $\mathrm{t}_{\text {count }}=-0,333>\mathrm{t}$ table $--2,035$ and significant value $0,742>\alpha=0,05$. Then it can be conclude that $\mathrm{H}_{0}$ accepted which means the application of sharia principles has no significant effect of customer satisfaction does not proven. so, it can be concluded that which making application of sharia principles has no effect on customer satisfaction level of murabahah financing in KJKS Mass Group in Central Java is because the lack of customers awareness on the importance of applying the principles of sharia in using the existing financial services.

Then on variable $\mathrm{X} 2$ that is services accordance to the data processing result above it proved that services variable partially has significant effect on customer satisfaction on murabahah financing in KJKS Mass Group in Central Java. It can be seen from the calculation result gained $\mathrm{t}_{\text {count }}=5,821>\mathrm{t}$ table $=2,035$ and significant value $0,000<\alpha=0,05$. Then it can be concluded that $\mathrm{H}_{0}$ rejected which means customers has significant effect on customers satisfaction on murabahah financing in KJKS Mass Group in Central Java. From this result show hypothesis $\left(\mathrm{H}_{2}\right)$ this research which states that service variable partially has significant effect on customer satisfaction proven true. Thus, it can be concluded that the main factors that affect the level of customer satisfaction in using financial services in KJKS Mass Group in Central Java is because of the service was done by KJKS itself to the customers. In the test can also be known the effect of Sharia Principles application and simultaneously Service to customer satisfaction of murabahah financing in KJKS Mass Group in Central Java, the test yields $F$ value of 30.613 with a significance level of 0.00 . Since the significance value is less than 0.05 and the $F$ value count (30.613) is bigger than F table (4.12) then $\mathrm{H}_{0}$ is rejected. So it can be concluded that the application of Sharia principles and services simultaneously has significant effect to the level of customer satisfaction on murabahah financing in KJKS Mass Group in Central Java. From this result shows the hypothesis $\left(\mathrm{H}_{3}\right)$ in the thesis that the variable Sharia principles application and services simultaneously has significant effect on customer satisfaction proved true. Thus, it can be concluded that what makes the application of Sharia principles and services combined to satisfy murabahah financing customers is because there is a significant service influence in it, while the application of Sharia principles is only a supporting factor in providing satisfaction to murabahah financing customers itself.

After that to know how much the influence of sharia principles application and service to the satisfaction of murabahah financing customer in KJKS Mass Group in Central Java, so researcher use Determination test $\left(\mathrm{R}^{2}\right)$. From the results of data processing is known value of adjusted coefficient of determination (adjusted $\mathrm{R}^{2}$ ) of 0.657 which means that independent variable is the application of Sharia principles and Services simultaneously affecting $65.7 \%$ of the dependent variable that is customer satisfaction, while the remaining $34.3 \%$ influenced by other variables outside the two variables used.

\section{Conclusion}

From the discussion above, it can be concluded that the result of $t$ test is proven partially has significant effect on satisfaction with the result of $t_{\text {count }}=5,821$ $>\mathrm{t}$ tabel $=2,035$. While the application of sharia principles variables patially has no significant effect on satisfaction with the result of $\mathrm{t}_{\text {count }}=-0,333>\mathrm{t}$ table $=-2,035$. Then from the result of $F$ test of both variables simultaneouly proven that it has significant effect on satisfaction with $\mathrm{f}_{\text {count }}$ 
International Journal of Economics, Business and Accounting Research (IJEBAR) .

Peer Reviewed - International Journal

Vol-2, Issue-1, 2018 (IJEBAR)

ISSN: 2614-1280, https://jurnal.stie-aas.ac.id/index.php/IJEBAR

$30,613>\mathrm{F}$ tabel 4,22. From the result of $\mathrm{R}^{2}$ test it is known that the effect of both variables is $65,7 \%$ againts dependent variable that is customer satisfcation, while the remaining $34.3 \%$ is influenced by other variables outside the two variables used.

\section{Acknowledgements}

In this research I would like to say much thanks to my lecturer colleagues in STIE AAS Surakarta who always provide support and direction for the completion of this research.

\section{References}

Arifin, Bustanul. (1974). Pelembagaan Hukum Islam. Jakarta: Bulan Bintang.

Budiono, Arif. (2017). "Penerapan prinsip syariah pada lembaga keuangan syariah". Jurnal Law And Justice Vol. 2 No. 1 (2017): 54-65.

Fajri, EM Zul dan Ratu Aprilia Senja. (2008). Kamus Lengkap Bahasa Indonesia. Edisi Revisi. Semarang: Difa Publishers. Cet. 3.

Jumantoro, Totok dan Samsul Munir Amin. (2005). Kamus Ilmu Ushul Fikih. Jakarta: Penerbit Amzah.

Kotler, Philip. (2002). Manajemen Pemasaran di Indonesia: Analisis, Perencanaan, Implementasi dan Pengendalian. Jakarta: Salemba Empat.

Kotler, Philip dan Gary Armstrong. (1996). Dasar-Dasar Pemasaran Principles of Marketing 7C. Jakarta: Penerbit Prenhallindo. Jilid 2.

Muhammad, (2009). Model-model Akad Pembiayaan di Bank Sharia. Yogyakarta: UII Pres.

Panjaitan, Januar Efendi dan Yuliati, Ai Lili. (2016). "Pengaruh Kualitas Pelayanan Terhadap kepuasan pelanggan pada JNE Cabang Bandung”. DeReMa Jurnal
Manajemen Vol. 11 No. 2. (2016): 265289.

Royne (1994) kualitas layanan menjadi komponen utama produk perbankan.

Tho'in, M. (2011). Pengaruh Faktor-faktor Kualitas Jasa terhadap Kepuasan Nasabah di Baitul Mal Wat Tamwil (BMT) Tekun Karanggede Boyolali. Muqtasid: Jurnal Ekonomi dan Perbankan Syariah, 2(1), 73-89.

Tho'in, M. (2016). Kompetensi Sumber Daya Manusia Bank Syariah Berdasarkan Prinsip-Prinsip Syariah Islam (Studi Kasus Pada BNI Syariah Surakarta). Jurnal Ilmiah Ekonomi Islam, 2(03).

Tjiptono, Fandy. (1997). Strategy Pemasaran. Yogyakarta: Andi offset. Edisi Kedua. Cet. Pertama. 